\title{
Fractura de cartílago tiroides
}

\section{Fracture of the thyroid cartilage}

\section{Marco Antonio Ayala-García ${ }^{1,2, a}$, Aldo Hugo Santoyo Saavedraa ${ }^{2, b}$, Olga Isidora Martínez Martínez MSc ${ }^{2, c}$}
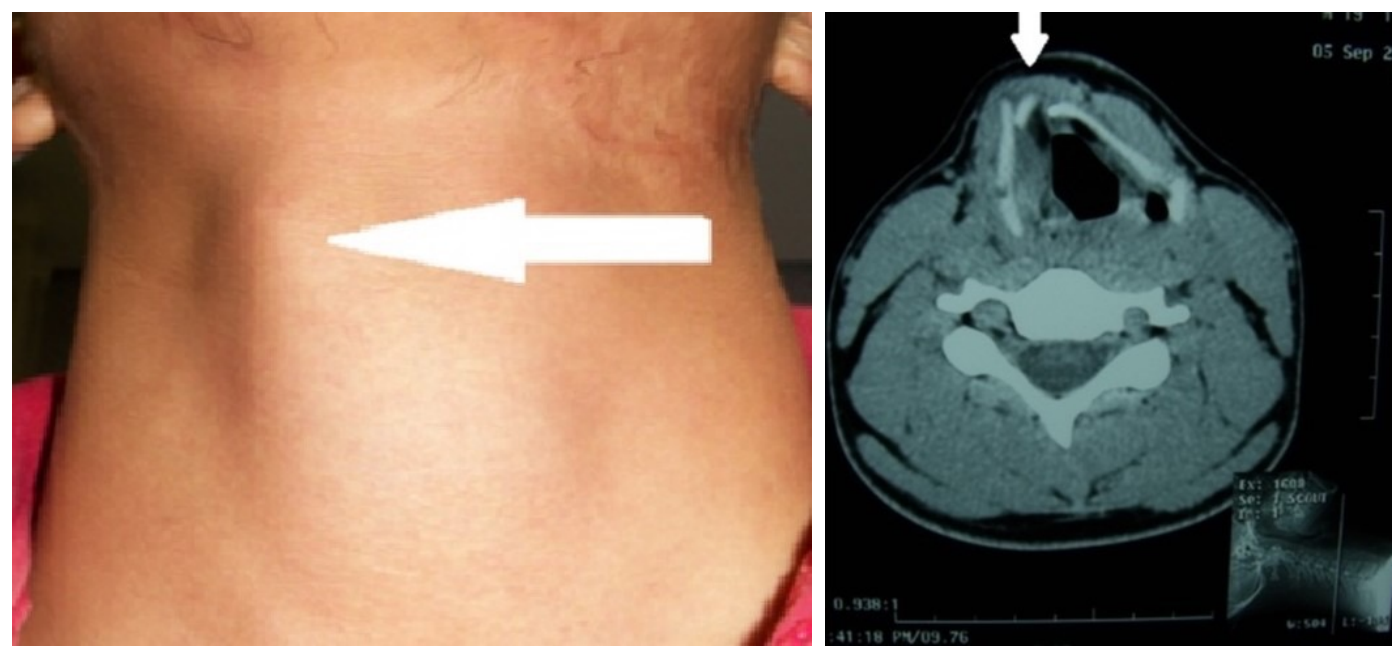

Varón de 20 años que acudió al servicio de urgencias por presentar trauma directo de cuello, refiriendo dolor en cuello. A la exploración física presentaba disfonía y desviación del cartílago tiroides hacia la derecha (flecha). En la laringoscopia directa, se encontró un pequeño hematoma en el lado derecho de la laringe, sin hemorragia activa. La tomografía de cuello evidenció fractura del cartílago tiroides, clasificación de Schaeffer EIII (fractura desplazada estable). El paciente fue tratado con esteroides, antibiótico y observación intrahospitalaria durante 24 horas, no presentando dificultad respiratoria ni exacerbación del cuadro. Fue dado de alta y se dio vigilancia mensual por un año, periodo en el cual estuvo asintomático y sin disfonía.

A 20-year-old male patient attended the emergency room after having a trauma on the neck. The physical examination revealed dysphonia and deviation of the cartilage thyroid to the right. A direct laryngoscopy showed a small hematoma on the right side of the larynx with no active bleeding. A CT scan of the neck revealed fracture of the cartilage thyroid. Schaeffer EIII (displaced stable fracture). The patient was treated with steroids, antibiotics and observation for 24 hours not presenting respiratory distress. The patient was discharged to be followed monthly for one year, period in which he was asymptomatic and with no dysphonia.

\section{Correspondencia:}

Dr. Marco Antonio Ayala García

Bosque Castaño No. 201-k, Col. El Dorado, CP 37590, León, Guanajuato, México.

Teléfono +52 (477) 2414826

Correo electrónico: drmarcoayala@hotmail.com

Servicio de Cirugía, Hospital General Regional No. 58 del IMSS, Delegación Guanajuato, México.

Comité de Investigación, Escuela de Medicina, Universidad Quetzalcóatl en Irapuato, Guanajuato, México..

$\mathrm{PhD} ;{ }^{\text {b. }} \mathrm{MD} ;{ }^{\text {c. }} \mathrm{MSc}$ 